\title{
Peertechz
}

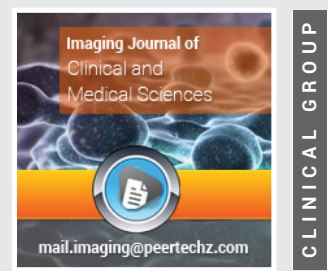

Clinical Image

\section{Exclusive Image Gallery on Human Spinal Cord Regeneration}

\section{Giselher Schalow*}

MD, PhD, Untere Kirchmatte 6, CH-6207 Nottwil, Switzerland

Received: 22 May, 2019

Accepted: 15 June, 2019

Published: 16 June, 2019

*Corresponding author: Giselher Schalow, Professor, Untere Kirchmatte 6, CH-6207 Nottwil, Switzerland, E-mail: g_schalow@hotmail.com

https://www.peertechz.com

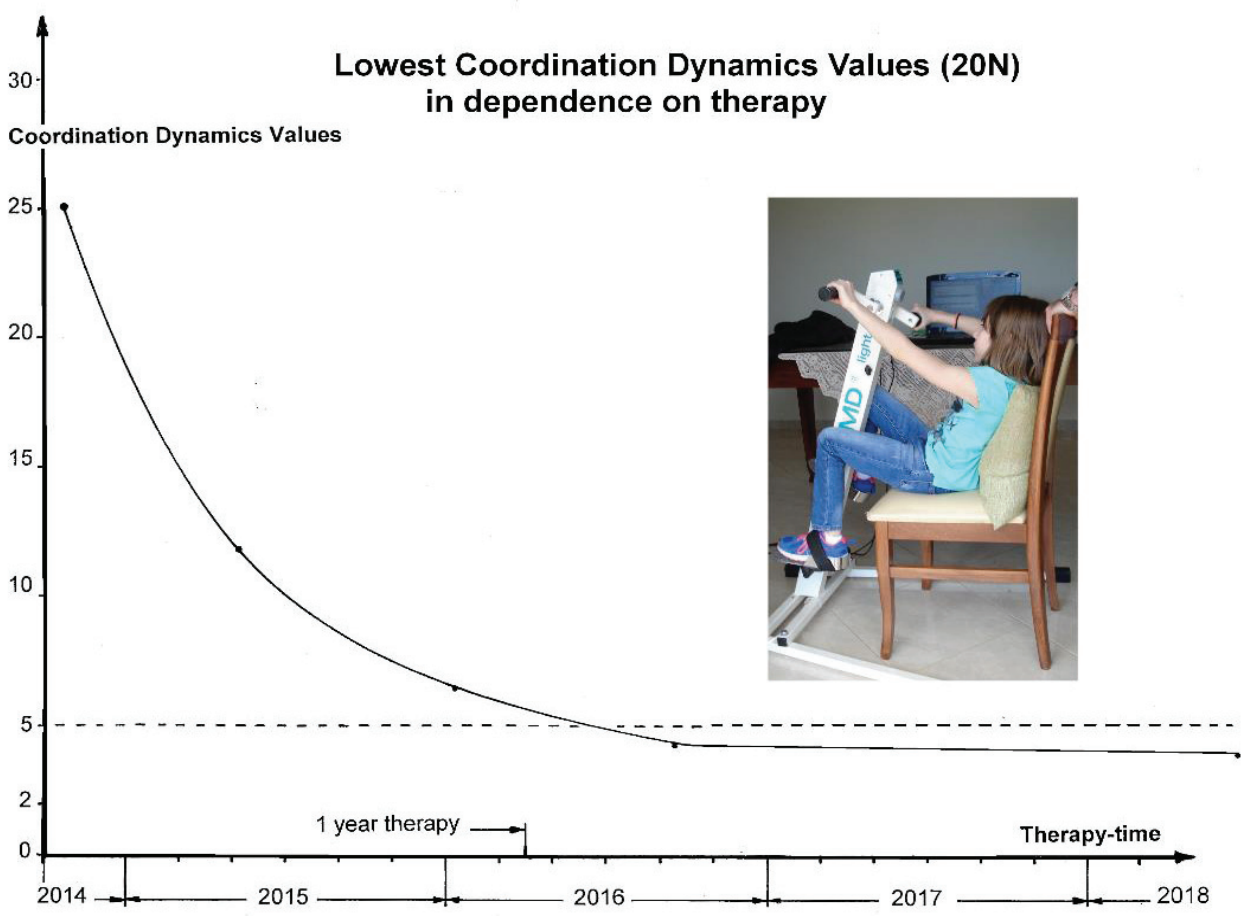

Figure 74: Improvement of the low load coordination dynamics best values with therapy.

Copyright: (C) 2019 Schalow G. This is an open-access article distributed under the terms of the Creative Commons Attribution License, which permits unrestricted use, distribution, and reproduction in any medium, provided the original author and source are credited. 